\title{
Are regional strategies for insect conservation feasible?
}

\author{
T. R. New
}

Published online: 8 January 2009

(C) Springer Science+Business Media B.V. 2009

The recently-published European Strategy for the Conservation of Invertebrates (Haslett 2007) brings together much information on the conservation needs and status of the world's most thoroughly documented insect fauna under the general goal of halting their decline, and underpinned by a list of seven main objectives to enhance their conservation (Appendix 1). The values of such endeavour, if it can be translated constructively into concerted practice, may be considerable. Haslett included lists of 'key actions' for each theme discussed. Potential exists for harmony or cooperative planning across political boundaries that fragment the natural range of many species and ecosystems of conservation concern, in order to foster range-wide management. Facilitation through greater economies of scale is already being demonstrated in Europe for groups such as butterflies, hoverflies and xylophagous beetles, amongst others. The prospect then follows that similar or parallel regional planning might be useful elsewhere in the world, perhaps using the European Strategy as a model. Several authors have recently compared and contrasted the problems facing effective insect conservation in different parts of the world, emphasizing differing capability and available knowledge between the northern and southern temperate regions (Samways 1995, Stewart and New 2007) and in the tropics (Lewis and Basset 2007). These differences initially appear formidable and likely to thwart any more general integrated planning for insect conservationbut is this really the case?

T. R. New $(\bowtie)$

Department of Zoology, La Trobe University, Melbourne,

VIC 3086, Australia

e-mail: T.New@latrobe.edu.au
The major drivers for any such plan include: (1) having sufficient knowledge to formulate a rational informed basic approach and, where necessary to augment it by intelligent precautionary measures; (2) an established conservation policy such as a Wildlife Protection Act, Endangered Species Act, initial Red List, or other conservation legislation or formal guidance toward priorities, not necessarily in all political areas of a region, that can endorse credibility; and (3) the goodwill to proceed, together with foundation locally-based capability and impetus to do so within the local socioeconomic climate. In addition, recognition of the importance of insects, and that this necessitates their conservation within the wider scenario of biodiversity protection, may dictate how local approaches and priorities may contribute to countering global embracing issues of habitat loss and climate change. Despite the fundamental need for scientific knowledge to pursue detail, this may actually be the least important of the above drivers, because sufficient framework usually already exists (see Janzen 1997) for local adaptations to build on the wider principles exemplified from better-known faunas, such as Europe. The principles underpinning Haslett's (2007) objectives have very broad application, and the major threats to insects are well-defined, at least in general terms, with many of them universal and their relative importance showing regional differences. Regional differences in information available on insect diversity and conservation need are largely those of scale, extent and detail, rather than paradigm shifts that determine major strategy for agreed common purpose. Whereas the minutiae of a European 'scene' may not transfer directly to the rest of the world, much insect conservation thought and planning elsewhere has historically been stimulated by approaches and examples from Europe and North America, in most cases giving way to locally pragmatic and independent effort. 
The vision of the European strategy ("A world in which invertebrate animals are valued and conserved, in parallel with all other groups of organisms, now and in the future') would, I suspect, be approved by all readers of this Journal. The difficulties of extending this are largely logistic and political, with the massive urgent needs of burgeoning human populations naturally taking precedence and leaving little room for the perceived luxury of conservation unless it can be linked convincingly with economic return-as by ecotourism or regulated supply of specimens for international markets. Nevertheless, the intent of each of Haslett's seven objectives transfers easily to any other part of the world, even though external imposition of those objectives is sometimes likely to meet resistance as 'interference'.

In practice, the infrastructure needed to support resolve (one of the strongest contributors to the European Strategy) is weak in many other places. Perhaps the two most central 'messages' to promote relate to: (1) the importance of insects per se and the grounds for their conservation, and (2) the place of insects in wider conservation needs, such as regulators of ecological processes and indicators of environmental changes, both topics discussed by New (2007). Many mechanisms may be available to help achieve this, but two appear to be particularly relevant at present, and could lay much of the foundation needed to stimulate interest. First, the World Conservation Union Species Survival Commission's Invertebrate Conservation SubCommittee are starting to promote wider activity in 'RedListing' species across a variety of selected taxa. This exercise could increasingly convey to many agencies and individuals the global importance and conservation needs of many of 'their' endemic or otherwise significant threatened species. It may be pivotal in helping to increase the profile of insects (and other invertebrates) in wider conservation agendas in which they are still largely ignored. That significance, despite having been demonstrated effectively in the northern temperate region, is still to become 'core conservation business' in much of the rest of the world. Second, many countries have national entomological societies or wider biological societies including invertebrate interests, through which —at least in principle if local impetus was forthcoming-national and, perhaps, regional conservation interests, needs and priorities could be appraised and promoted. Some already have a conservation committee or similar interest group. For one important regional example, the Neotropics, Hogue (1993) listed national entomological societies in Argentina, Brazil, Chile, Mexico, Peru and Uruguay, with most other countries in the region having relevant 'interest-groups', publications and institutions. Similar listings could be made for other regions, and the existing defined regional 'sections' of the Society for Conservation Biology (namely
Asia, Australasia, Africa, Austral and Neotropical America, and North America, in addition to Europe) indicate likely support for regional conservation activities.

Perhaps the most fundamental initial step is for national needs and priorities to be formulated strongly, and for the common ground across regions to be then explored. However, one could equally argue a case to first assess global needs, and subsequently tailor more local efforts to contribute to solving those, although this approach may be seen as external interference unless supported strongly by local interests. Whichever approach may prevail, agreed general principles of need are, at this stage, more important than excessive detail. Promotion of a series of regional forums toward this end would be a sound investment in the future for insect conservation. Haslett's welcome document has indicated ways forward: it is now up to others to take up the challenge.

In the Australian film 'The Castle' (1997), the character Darryl Kerrigan, played by Michael Caton, utters the nowfamous catch phrase 'Tell him he's dreaming!', and I can imagine a number of readers and colleagues saying something similar, perhaps in rather stronger language! Ideas for wider strategies for insect conservation are not novel: a 'Mission' for the projected Species Survival Commission Invertebrate Conservation Task Force in the early 1990s was 'To coordinate and enhance efforts to understand and prevent loss of invertebrate animal taxa and their populations worldwide'. A major purpose of IUCN Recommendation No 18/41 (1990) (Conservation of insects and other invertebrates) was to facilitate such a plan (see Collins 1991 for full text). Amongst other topics, this Recommendation urged governments to (1) draft their national protective legislation recognising that the primary threat to insects and other invertebrates is habitat destruction; (2) broaden the scope and context of existing international conventions to make them more appropriate for insects, other invertebrates, and particularly their habitats; and (3) promote practical recovery plans for invertebrate species already listed in national legislation and international conventions. Further commentary was given by New (1995). But much of this advocacy, even through the world's leading conservation organization, has had little influence other than in the most affluent parts of the world. Surely, then, 'dreaming' is worthwhile, particularly as an alternative to accepting the nightmare of mass losses of insects and the services they provide, unless urgent conservation actions are forthcoming.

Acknowledgements I very much appreciate comments from Professors Roger Dennis and Michael Samways on a draft of this note; their views should not be taken as necessarily coinciding with mine. The text of Appendix 1 is reproduced with permission from the Council of Europe (Publishing Division). 


\section{Appendix 1}

The seven objectives of the European Strategy (Haslett 2007, p. 14) (copyright text reproduced by permission of the Council of Europe)

1. Raise awareness and alter human attitudes and behaviour towards the importance of conserving invertebrate animals;

2. Promote integrated management of landscape mosaics at the relevant scales to be sustainable for invertebrates;

3. Strengthen European to national/sub-national invertebrate conservation policy and action;

4. Identify and prioritise key actions to be implemented at different political and geographical levels;

5. Promote accessibility and efficient flow and exchange of information on invertebrates within and between the scientific and public domains;

6. Promote inclusion of a fully representative variety of invertebrate species in conservation and environmental management decisions, including integration of invertebrate conservation into existing and future conservation strategies involving other groups of organisms

7. Build scientific and technical capacity for the conservation of invertebrates and identify areas of urgent further research

\section{References}

Collins NM (1991) Insect conservation-priorities for the future. Antenna 15:73-78

Haslett JR (2007) European strategy for the conservation of invertebrates. Nature and environment, No 145, Council of Europe Publishing, Strasbourg

Hogue CL (1993) Latin American insects and entomology. University of California Press, Berkeley

Janzen DH (1997) Wildlife biodiversity management in the tropics. In: Reaka-Kudla ML, Wilson DE, Wilson EO (eds) Biodiversity II: Understanding and protecting our biological resources. National Academy of Sciences, Washington DC, pp 411-431

Lewis OT, Basset Y (2007) Insect conservation in tropical forests. In: Stewart AJA, New TR, Lewis OT (eds) Insect conservation biology. CABI, Wallingford, pp 34-56

New TR (1995) Introduction to invertebrate conservation biology. Oxford University Press, Oxford

New TR (2007) Broadening benefits to insects from wider conservation agendas. In: Stewart AJA, New TR, Lewis OT (eds) Insect conservation biology. CABI, Wallingford, pp 301-321

Samways MJ (1995) Southern hemisphere insects: their variety and the environmental pressures upon them. In: Harrington R, Stork NE (eds) Insects in a changing environment. Academic Press, London, pp 298-320

Stewart AJA, New TR (2007) Insect conservation in temperate biomes: issues, progress and prospects. In: Stewart AJA, New TR, Lewis OT (eds) Insect conservation biology. CABI, Wallingford, pp 1-33 